\section{(2) OPEN ACCESS}

\title{
Analysis of the illicit tobacco market in Georgia in response to fiscal and non-fiscal tobacco control measures
}

\author{
Megan Little $\odot,{ }^{1}$ Hana Ross, ${ }^{1}$ George Bakhturidze, ${ }^{2}$ lago Kachkachishvili ${ }^{3}$
}

\begin{abstract}
${ }^{1}$ School of Economics, Research Unit on the Economics of Excisable Products, University of Cape Town, Rondebosch, Western Cape, South Africa ${ }^{2}$ Tobacco Control Research, FCTC Implementation and Monitoring Center in Georgia, Tbilisi, Georgia

${ }^{3}$ Sociology and Social Work Department, Ivane Javakhishvili Tbilisi State University, Tbilisi, Georgia
\end{abstract}

\section{Correspondence to} Megan Little, School of Economics, Economics of Excisable Products Research Unit, University of Cape Town, Rondebosch, Western Cape 7701, South Africa; firdaleconsulting@gmail.com

Received 4 December 2020 Revised 18 April 2021 Accepted 27 April 2021
Check for updates

(C) Author(s) (or their employer(s)) 2021. Re-use permitted under CC BY. Published by BMJ.

To cite: Little M, Ross $\mathrm{H}$, Bakhturidze G, et al. Tob Control Epub ahead of print: [please include Day Month Year]. doi:10.1136/ tobaccocontrol-2020-056404
ABSTRACT

Background Georgian illicit cigarette consumption was $1.5 \%$ in 2017. In 2018, a new tobacco control law took effect followed by a substantial cigarette excise tax increase in 2019. Research shows these policies reduce tobacco consumption, but the tobacco industry argues they increase illicit trade. There is limited evidence on this, particularly from developing countries.

Methods A panel household survey in Georgia obtained data over three waves: 2017 baseline, 2018 after the tobacco control law took effect and 2019 after taxes increased. A sample of 1578 smokers (and quitters in later waves) from five regions reported their tobacco use and were asked to present a cigarette pack in their possession. These were examined for tax stamps and health warnings to establish legality.

Findings There was no evidence of an increase in illicit cigarette consumption in Tbilisi, Kutaisi, Akhaltsikhe or Gori in any wave. In Zugdidi, near the Russian-occupied Abkhazia, illicit cigarette consumption was increasing even prior to the tax increase, reaching $30.9 \%$ by wave 3. A country-wide shift occurred from manufactured cigarettes to roll-your-own tobacco (whose tax remained unchanged) between waves 2 and 3 .

Conclusion No evidence of a country-wide increase in illicit cigarette trade was found after non-fiscal tobacco measures took effect and cigarette taxes increased. Relatively high illicit cigarette consumption in Zugdidi highlights the role of disputed territories and border administration in illicit cigarette supply. Substitution towards roll-your-own tobacco after manufactured cigarette taxes increased demonstrates the importance of equalising taxes on tobacco products to maximise public health benefits.

\section{INTRODUCTION}

Georgia has high tobacco use prevalence, estimated at $55 \%$ for men and $12 \%$ for women in $2016 .{ }^{1}$ To reduce tobacco use and improve public health, the government passed a new tobacco control law in 2017 which came into effect in 2018, and increased cigarette excise tax in 2019.

The new tobacco control law introduced pictorial health warnings, banned smoking in almost all public places and severely limited tobacco advertising. ${ }^{2}$ The 2019 tax reform equalised the specific excise tax rate on filtered and unfiltered cigarettes by increasing the unfiltered tax rate 2.8 times (from 60 tetri to 1.70 Georgian lari (GEL) per 20 cigarettes) and increased the ad valorem tax rate from $10 \%$ to $30 \%$ on filtered cigarettes. ${ }^{3}$
While the impact of higher tobacco taxes on lowering tobacco use has been widely documented, ${ }^{4}$ there is limited research on the effect of fiscal and non-fiscal policies on illicit tobacco trade. The tobacco industry assertions that tobacco tax increases will only increase illicit tobacco consumption make governments hesitant to increase taxes. ${ }^{4}$

Recent studies showed either no link or a weak link between tax increases and consumption of illicit cigarettes. For example, in Mongolia the share of illicit consumption fell after import and excise taxes rose in 2017 and 2018, respectively. ${ }^{5}$ Despite substantial tax increases in Latin America during the 2000s, there was no statistical evidence of illicit tobacco trade increases in Colombia or Peru. ${ }^{6}$

In the early 2000s, the illicit cigarette market was rampant in Georgia reaching one-third to twothirds of the total cigarette market. ${ }^{7}$ Since then, the illicit cigarette market share has fallen dramatically to an estimated $1.5 \%$ of the total market in 2017 (research used the same wave 1 data used in this paper). ${ }^{8}$ This was the result of improved tax administration and reforms to the country's revenue and custom services. ${ }^{4}$ The reduction in the illicit cigarette market share coincided with increases in Georgia's tobacco tax rates. ${ }^{8}$ However, the direct impact of higher excise tax on the illicit tobacco market in Georgia has not been studied yet.

Employing household-level data, this paper examines the effect of two events on the illicit cigarette market in Georgia: the implementation of a new tobacco control law in 2018 focusing on nonfiscal measures, and a substantial tobacco excise tax increase in 2019.

\section{METHODOLOGY}

As shown in figure 1, a panel of smokers (and former smokers in follow-up waves) located in five regions of Georgia (Tbilisi, Kutaisi, Zugdidi, Akhaltsikhe and Gori) was surveyed three times: in November 2017, in December 2018 (after the tobacco control law was enacted in May 2018) and in May 2019 (after the cigarette tax was increased in January 2019). Our choice of the survey method to study illicit trade in Georgia was informed by a systematic review of various methodologies ${ }^{9}$ and the budget available for the study.

The five regions surveyed represented the geographical diversity of Georgia and/or likely illicit trade hot spots given their proximity to borders (see figure 2). In 2017, the total Georgian population was 3726 400, with 1145500 living in the city of Tbilisi, 142800 in Kutaisi municipality, 104200 in 


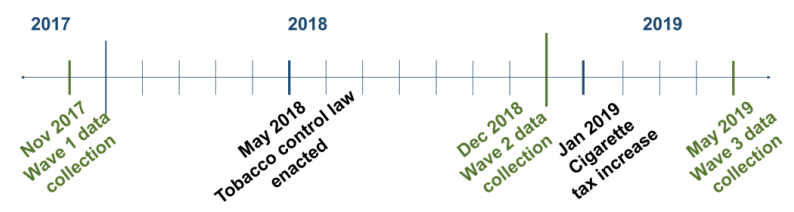

Figure 1 Project timeline.

Zugdidi municipality, 39300 in Akhaltsikhe municipality and 123800 in Gori municipality. ${ }^{10}$ These five regions therefore represented $41.2 \%$ of the total Georgian population. In 2017, our survey interviewed 2997 individuals $(0.1 \%$ of the total Georgian population) with 997 (0.01\%) individuals in Tbilisi, $498(0.4 \%)$ in Kutaisi, $500(0.5 \%)$ in Zugdidi, 500 (1.3\%) in Akhaltsikhe and $502(0.4 \%)$ in Gori.

Respondents provided basic demographic information and reported the type of tobacco used, frequency, quantity and knowledge of illicit tobacco consumption in their region. In addition, respondents were asked to show a cigarette pack to be examined for brand, price, and the presence of a Georgian tax stamp and health warning. The surveys conducted in all three waves were similar in format, with a few extra questions added in wave 3 to ascertain any behavioural changes resulting from the new law and tax increase.

The sampling began with urban and rural stratification, followed by the selection of primary sampling units (census units in urban strata and villages in rural strata) proportional to population size. Secondary sampling units (households) were then selected using the 'random step method'-adopted for its cost-effectiveness and because there were households in Georgia without addresses.

If no smokers resided in the selected household, a short general survey was administered to the first adult person answering the door. If the household had a smoker, all smokers were listed and one was randomly selected for the interview. If the selected respondent refused or was not home during any of the three interview attempts, another smoking resident was selected. If no smoking residents were available for interview, the household was recorded as 'non-responding' and the interviewer walked past five households on average (the number varied slightly for urban and rural strata) and selected a replacement household.

Table 1 shows that surveyors completed 2997 interviews in wave 1 . Of those, 1765 people were successfully re-interviewed in wave 2. These were supplemented with new households (also selected using the 'random step method') which brought the total

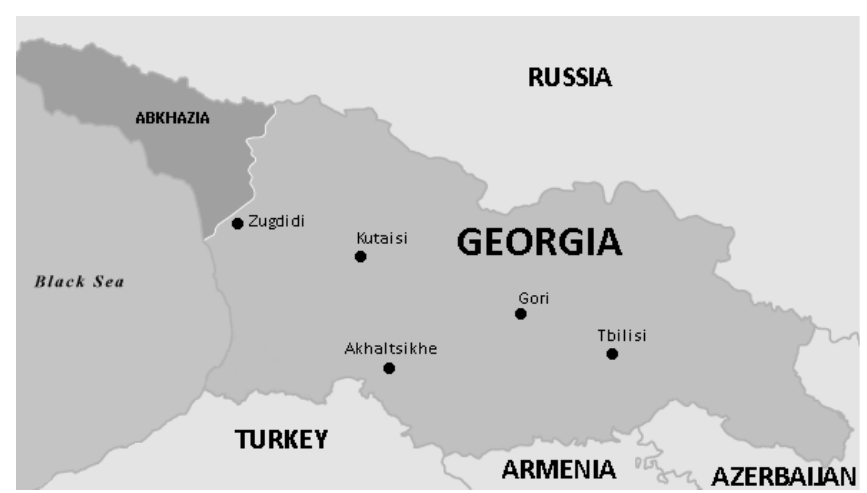

Figure 2 Map of Georgia.
Table 1 Response rates by wave

\begin{tabular}{lrrrrrr}
\hline & \multicolumn{2}{c}{ Wave 1 } & \multicolumn{2}{c}{ Wave 2 } & \multicolumn{2}{c}{ Wave 3 } \\
\hline Interviewed & 2997 & $68.9 \%$ & 3040 & $70.8 \%$ & 3189 & $76.7 \%$ \\
No tobacco users reside & 957 & $22.0 \%$ & 191 & $4.5 \%$ & 384 & $9.2 \%$ \\
Non-respondents & 390 & $8.9 \%$ & 1061 & $24.7 \%$ & 584 & $14.1 \%$ \\
Total & 4344 & \multicolumn{3}{c}{4292} \\
\hline $\begin{array}{l}\text { Non-respondents included those who refused to participate, were not home or had moved away since } \\
\text { a previous wave. }\end{array}$
\end{tabular}

people interviewed in wave 2 to 3040 . In wave 3 , there were 1578 people interviewed in both waves 1 and 2 (our panel), 240 people interviewed in wave 1 but not in wave 2, 1036 people only interviewed in wave 2 , and 335 people added in wave 3 for the first time. As such, there were 3189 people interviewed in wave 3 . For quality control, an independent controller crosschecked a randomly selected $10 \%$ of completed interviews in each wave and no major errors were identified.

The total attrition in our panel was $52.6 \%$ with attrition varying significantly by region. The highest rate was in Tbilisi (62.7\%) followed by Kutaisi (52.2\%), Akhaltsikhe (47.4\%), Gori (31.9\%) and Zugdidi (27.4\%). Within each region, there was no significant difference in the likelihood of attrition by gender, employment, the probability of showing a pack or the probability of owning an illicit pack. Given the attrition patterns, the analysis was done by region wherever possible.

To establish the rates of illicit cigarette consumption, those respondents who indicated they smoked cigarettes were asked to show the interviewer an available cigarette pack. On examination, the packs lacking either a health warning or tax stamp (required by law $^{4}$ ) were defined as illicit. Georgia's tax stamps are secured by a proprietary technology and cannot be removed from a pack without damaging both the packs and the tax stamps. ${ }^{11}$ All statistics extrapolated to be representative of the populations in the five regions are followed by CIs at the $95 \%$ level to order to establish statistical significance.

We explored whether illicit cigarette consumption was correlated with changes in both fiscal and non-fiscal measures by comparing illicit cigarette consumption rates at the baseline with the midline (after the non-fiscal changes) and with the endline (after the tax increase). Even though the broader economic environment in Georgia was fairly stable during this period with the real gross domestic product growth between $4.8 \%$ and $5 \%,{ }^{12}$

Table 2 Percentage of people, by demographic characteristic in wave 1

\begin{tabular}{|c|c|}
\hline & Wave $1(\mathrm{Cl})$ \\
\hline Gender: male (\%) & $89.7(88.1$ to 91.1$)$ \\
\hline Age bracket: $18-29$ years $(\%)$ & $19.7(17.8$ to 21.7$)$ \\
\hline Age bracket: $30-49$ years (\%) & $46.2(43.8$ to 48.7$)$ \\
\hline Age bracket: 50 years and older (\%) & 34.2 (31.9 to 36.5$)$ \\
\hline Education: less than secondary school (\%) & $6.6(5.5$ to 7.9$)$ \\
\hline Education: secondary school complete (\%) & 43.3 (40.9 to 45.8$)$ \\
\hline Education: vocational education complete (\%) & $12.1(10.5$ to 13.8$)$ \\
\hline Education: tertiary education incomplete (\%) & 3.9 (3.1 to 5.0$)$ \\
\hline Education: tertiary education complete (\%) & 34.1 (31.9 to 36.5$)$ \\
\hline Mean household size (number of people) & 3.6 (3.5 to 3.6$)$ \\
\hline $\begin{array}{l}\text { Employment status: employed in private or public } \\
\text { sector (\%) }\end{array}$ & $28.4(26.2$ to 30.7$)$ \\
\hline Employment status: self-employed (\%) & 31.9 (29.6 to 34.3$)$ \\
\hline Employment status: unemployed (\%) & $29.7(27.5$ to 32.0$)$ \\
\hline Employment status: not in labour force (\%) & $10.0(8.6$ to 11.6$)$ \\
\hline
\end{tabular}

Little M, et al. Tob Control 2021;0:1-6. doi:10.1136/tobaccocontrol-2020-056404 
Table 3 Percentage of people, by reason for quitting smoking since previous wave

\begin{tabular}{lll}
\hline & Reported in wave 2 & Reported in wave 3 \\
\hline Health & $48.5 \%, \mathrm{Cl}(42.2 \%$ to $54.9 \%)$ & $16.3, \mathrm{Cl}(11.1 \%$ to $23.3 \%)$ \\
$\begin{array}{l}\text { Cost } \\
\begin{array}{l}\text { Both health and } \\
\text { cost }\end{array}\end{array}$ & $\mathrm{N} / \mathrm{A} .3 \%, \mathrm{Cl}(38.1 \%$ to $50.7 \%)$ & $49.0 \%, \mathrm{Cl}(40.9 \%$ to $57.1 \%)$ \\
Other & $7.2 \%, \mathrm{Cl}(4.5 \%$ to $11.3 \%)$ & $25.8 \%, \mathrm{Cl}(19.4 \%$ to $33.6 \%)$ \\
\hline
\end{tabular}

The survey was administered slightly differently in wave 2 and wave 3: respondents could select only one reason in wave 2 while in wave 3 they could select more than one reason.

$\mathrm{N} / \mathrm{A}$, not available.

and the average annual inflation between $3 \%$ and $5 \%,{ }^{13}$ we cannot ascertain causation.

In addition to the household survey, qualitative data were gathered through three focus group discussions (FGDs) with 8-10 participants in each group in Tbilisi, Gori and Zugdidi in December 2018 to obtain additional context of both licit and illicit cigarette consumption. The participants were of both genders, different ages and social status, and were mainly smokers or people from smokers' families. The purpose of the focus groups was to understand why a relatively large percentage of respondents refused to show their cigarette packs to a surveyor. This informed a small change in the questionnaire in waves 2 and 3, where respondents were asked about their cigarettes' tar content immediately before being asked to show a pack, to encourage people to show packs by shifting the focus from illicit cigarettes (and a possible unease about smoking them).

\section{RESULTS}

We present results for the respondents who responded to all three surveys (the panel), unless otherwise stated. The demographic characteristics of all panel respondents in wave 1 (extrapolated to the population) are presented in table 2. There was no evidence that demographics were statistically significantly correlated with attrition.

Between waves 1 and 2 (360 days apart), 9.1\%, CI $(7.9 \%$ to $10.5 \%$ ) of wave 1 smokers had given up smoking. By wave 3 (500 days after wave 1), nearly two-thirds of these people remained non-smokers: $5.6 \%$, CI (4.7\% to $6.8 \%)$ of wave 1 smokers were still non-smokers in wave 3 , while $3.5 \%$, CI $(2.7 \%$ to $4.4 \%)$ of wave 1 smokers quit in wave 2 but re-initiated smoking by wave 3. Among people who smoked in both wave 1 and wave 2, 5.2\%, CI (4.3\% to 6.4\%) had given up smoking by wave 3 (140 days after wave 2). There was no evidence that the reported quit rates were affected by attrition bias.

Table 3 shows that the main reasons for quitting reported in wave 2 (after the new tobacco control law came into effect) were health (48.5\%) and affordability (44.3\%), while $7.2 \%$ cited other reasons (predominantly that they did not know the reason they quit). Wave 2 smokers who gave up smoking by wave 3 (after the tax increase) cited affordability as the predominant cause for quitting. In total, nearly $75 \%$ of those who quit in wave 3 cited either only cost or both cost and health as their
Table 5 Percentage of respondents that showed packs, by wave

\begin{tabular}{llll}
\hline & Wave 1 & Wave 2 & Wave 3 \\
\hline Total & $74.2 \%$ & $82.7 \%$ & $67.2 \%$ \\
\hline Tbilisi & $85.8 \%$ & $88.3 \%$ & $83.7 \%$ \\
\hline Kutaisi & $72.7 \%$ & $77.6 \%$ & $64.2 \%$ \\
Zugdidi & $63.2 \%$ & $74.6 \%$ & $48.1 \%$ \\
\hline Akhaltsikhe & $78.7 \%$ & $90.1 \%$ & $72.0 \%$ \\
\hline Gori & $70.6 \%$ & $83.3 \%$ & $71.6 \%$ \\
Male & $72.5 \%$ & $81.8 \%$ & $64.5 \%$ \\
\hline Female & $90.0 \%$ & $90.7 \%$ & $84.3 \%$ \\
Employed or self-employed & $76.6 \%$ & $85.0 \%$ & $70.0 \%$ \\
Unemployed & $68.3 \%$ & $78.6 \%$ & $60.0 \%$ \\
\hline
\end{tabular}

reason for quitting, while $42 \%$ cited only health or both cost and health as their reason. Nearly $9 \%$ of wave 3 quitters cited other reasons such as inconvenience due to the public smoking ban or disliking the negative health images on packs.

Roll-your-own (RYO) tobacco increased in popularity, particularly after the cigarette tax increase between waves 2 and 3 (see table 4). While nearly all tobacco users in the five regions consumed only manufactured cigarettes in wave 1 and wave 2 , by wave 3 this share had dropped and the share of people consuming RYO tobacco increased. In all three waves, the majority of manufactured cigarettes consumed were imported: $81.4 \%$, CI $(79.4 \%$ to $83.3 \%)$ of manufactured cigarettes were imported in wave $1 ; 80.3 \%$, CI (78.2\% to $82.2 \%)$ in wave 2 and $91.7 \%$, CI (90.0\% to $93.2 \%)$ in wave 3 .

Wave 3 smokers were asked how the new tobacco control law and tax increase impacted their behaviour. In response to the new law, about $49.0 \%$, CI (47.2\% to $50.1 \%)$ of wave 3 smokers reported no change in behaviour; $17.6 \%$, CI $(16.3 \%$ to $19.0 \%)$ smoked at home instead of in public; $16.7 \%$, CI $(15.4 \%$ to $18.1 \%$ ) switched to another type of tobacco product; $1.5 . \%, \mathrm{CI}$ $(1.1 \%$ to $2.0 \%)$ continued to smoke in public places illegally; and $1.4 \%$, CI $(1.1 \%$ to $1.9 \%)$ consumed less tobacco. Only $3.5 \%$, CI $(2.9 \%$ to $4.2 \%)$ of smokers were unaware of the new law.

Regarding the tax increase, $5.2 \%$, CI (4.5\% to $6.1 \%)$ of wave 3 smokers were unaware the tax had increased; $43.3 \%$, CI (41.7\% to $45.1 \%$ ) kept their behaviour unchanged; $21.0 \%$, CI (19.5\% to $22.3 \%)$ consumed less tobacco; $14.0 \%$, CI $(12.8 \%$ to $15.2 \%)$ chose to shop in a new location or buy a new brand; and $11.7 \%$, CI (10.6\% to $12.9 \%)$ changed to RYO.

In each wave, respondents who smoked manufactured cigarettes were asked to show surveyors their cigarette pack (see table 5). In wave $1,74.2 \%$ showed a pack, which rose to $82.7 \%$ in wave 2. However, this percentage fell to $67.2 \%$ in wave 3 . The highest level of cooperation was in Tbilisi, while the lowest was in Zugdidi, a city in the western part of the country close to Abkhazia (occupied by Russia). Overall, women and employed respondents were more willing to show their packs than men and unemployed respondents. There was no substantial difference in proportion of respondents that showed packs by age.

Table 4 Percentage of people, by tobacco type consumed each wave

\begin{tabular}{lllc}
\hline & Wave 1 & Wave 2 & Wave 3 \\
\hline Manufactured cigarettes & $97.3 \%, \mathrm{Cl}(96.5 \%$ to $98.0 \%)$ & $96.3 \%, \mathrm{Cl}(95.3 \%$ to $97.2 \%)$ & $72.2 \%, \mathrm{Cl}(70.0 \%$ to $74.4 \%)$ \\
\hline Manufactured cigarettes and RYO & $1.0 \%, \mathrm{Cl}(0.6 \%$ to $1.7 \%)$ & $0.5 \%, \mathrm{Cl}(0.3 \%$ to $1.0 \%)$ & $4.3 \%, \mathrm{Cl}(3.4 \%$ to $5.5 \%)$ \\
\hline RYO only & $1.0 \%, \mathrm{Cl}(0.6 \%$ to $1.7 \%)$ & $2.8 \%, \mathrm{Cl}(2.1 \%$ to $3.7 \%)$ & $23.3 \%, \mathrm{Cl}(21.3 \%$ to $25.5 \%)$ \\
\hline Only other tobacco & $0.7 \%, \mathrm{Cl}(0.4 \%$ to $1.3 \%)$ & $0.4 \%, \mathrm{Cl}(0.2 \%$ to $0.9 \%)$ & $0.1 \%, \mathrm{Cl}(0 \%$ to $0.4 \%)$ \\
\hline
\end{tabular}

RYO, roll-your-own.

Little M, et al. Tob Control 2021;0:1-6. doi:10.1136/tobaccocontrol-2020-056404 


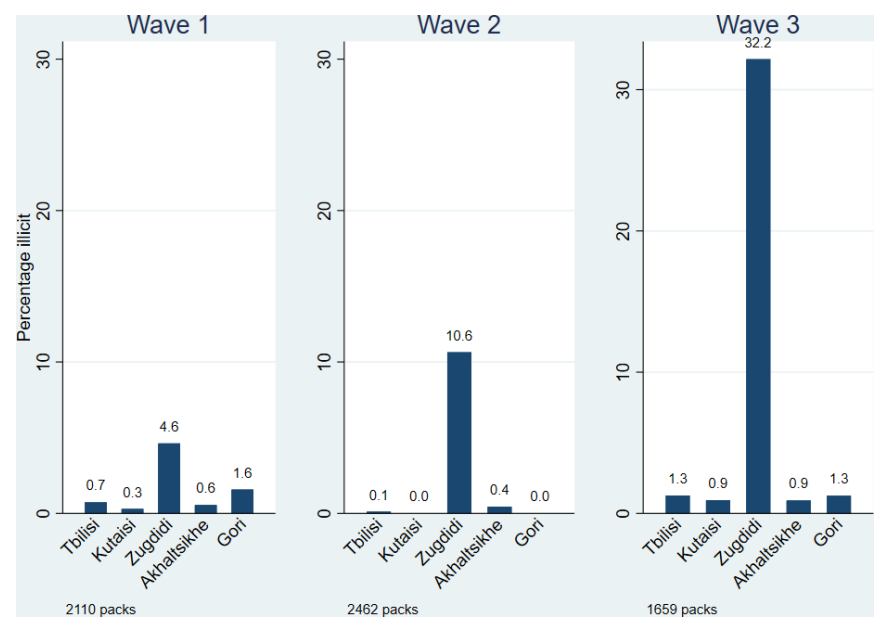

Figure 3 Percentage of illicit cigarette packs, by region.

The FGDs suggested possible reasons for the hesitation to show a pack which included embarrassment to show a cheap brand if respondents had reported smoking a more expensive brand, or that respondents were attempting to hide their smoking habit thus had no pack at home (particularly among women and youth). Some participants in Tbilisi speculated that the reason was to avoid showing an illicit pack, but they also noted that they had not seen illicit cigarettes in Tbilisi for a long time. The FGD in Zugdidi suggested that respondents may conceal an illicit pack to protect the vendor from which they bought it, although they were unlikely to worry about any personal consequences for having one illicit pack.

All available packs were examined and classified as illicit if they lacked either the Georgian tax stamp or the Georgian health warning. Robustness checks were performed and the illicit consumption results did not differ statistically significantly between all packs versus packs just from the panel, or when we defined packs with Georgian health warnings but missing or unclear tax stamps as licit. This was true for the overall sample and for all regions.

In waves 2 and 3, there were 9 and 27 packs, respectively, that had Georgian tax stamps and English health warnings. This is only legal for Duty Free packs, however none of these packs were found in Tbilisi where Duty Free shops are located. In both waves, over $75 \%$ of these packs were recorded by the same interviewer and as such we assumed this was an error and these packs

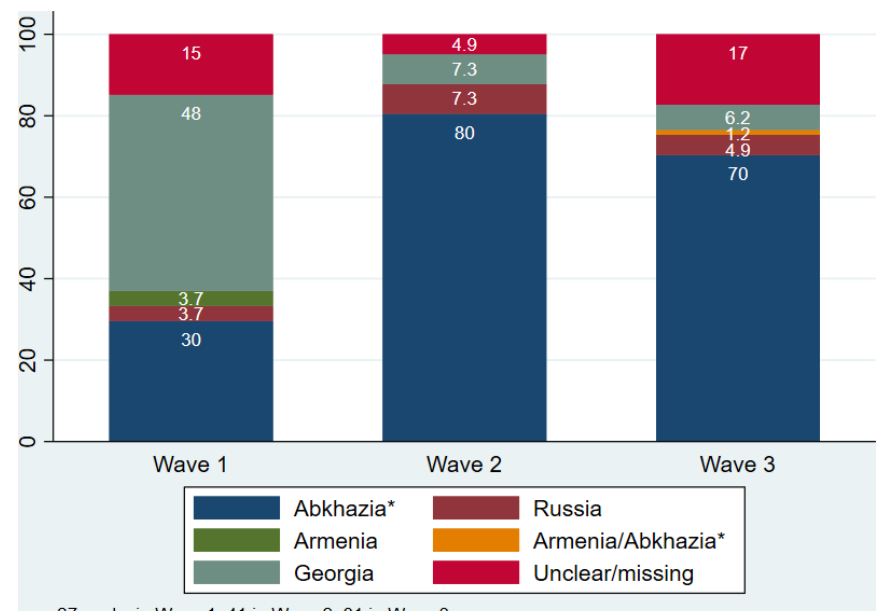

27 packs in Wave 1,41 in Wave 2, 81 in Wave 3

Figure 4 Percentage of illicit packs by country of origin, by wave. had their illicit status marked as missing. A sensitivity analysis was conducted, and no statistically significant difference was found in the percentage of illicit packs by region when these packs were defined as licit.

Figure 3 shows that there was no statistically significant rise in the proportion of illicit packs in Tbilisi, Kutaisi, Akhaltsikhe or Gori between waves 1 and 3. In Zugdidi, the percentage of smokers with illicit packs rose from $4.6 \%$, CI $(2.7 \%$ to $7.8 \%)$ in wave 1 to $10.6 \%$, CI $(7.8 \%$ to $14.3 \%)$ in wave 2 , and further to $32.2 \%$, CI (26.0\% to $39.0 \%)$ in wave 3. Within Zugdidi, there was no observed statistically significant difference in the ownership of illicit packs by employment status or age, and the gender difference could not be determined due to the limited number of observations.

All illicit packs were further examined first for foreign tax stamps and then for foreign language health warnings. This yielded a probable country (or occupied territory) of origin for most illicit packs. There were 27 illicit packs in wave 1, 41 in wave 2 and 81 in wave 3 . The proportion of illicit packs originating from Abkhazia was $29.6 \%$, CI (14.8\% to 50.4\%) in wave 1 (8 packs); $80.5 \%$, CI (64.8\% to $90.2 \%)$ in wave 2 (33 packs); and $70.4 \%$, CI (59.3\% to $79.5 \%$ ) in wave 3 (57 packs) (figure 4 ). While the increase from wave 1 to 2 was statistically significant, the decrease from wave 2 to 3 was not. The percentage of packs that had Georgian health warnings but no tax stamp fell from $48.2 \%$, CI (29.3\% to $67.5 \%)$ in wave 1 (13 packs), to $7.3 \%$, CI $(2.3 \%$ to $21.2 \%)$ in wave 2 (3 packs), and $6.2 \%$, CI $(2.5 \%$ to $14.2 \%$ ) in wave 3 ( 5 packs).

Among licit cigarette packs, the most popular brands were Winston (imported) and Pirveli (domestically produced). On average across the waves, Winston represented $13.0 \%, \mathrm{CI}$ (12.2\% to $13.9 \%)$ of the market and Pirveli represented $14.9 \%$, CI (14.0\% to $15.8 \%)$, while no other brands represented more than $10 \%$ of the market. Table 6 provides information on the illicit cigarette brands. Most illicit packs were international brands but there were some Georgian brands classified as illicit due to a missing tax stamp. The Manchester brand, clearly dominates, representing $33.3 \%$ of all illicit packs in wave $1,83.0 \%$ in wave 2 and $66.3 \%$ in wave 3 . In all three waves, the illicit Manchester packs were found only in Zugdidi and the majority had an Abkhazian tax stamp.

The analysis of price per pack (self-reported by the smoker) in figure 5 shows that the average price of the licit packs was GEL 3.6, CI (3.5 to 3.6) in wave 1; GEL 3.7, CI (3.6 to 3.7) in wave 2 and GEL 5.0, CI (4.9 to 5.0) in wave 3. In comparison, the average price of the illicit packs was GEL 2.7 , CI $(2.3$ to 3.0) in wave 1; GEL 2.1, CI (2.0 to 2.2) in wave 2 and GEL 2.8, CI (2.4 to 3.1$)$ in wave 3 . In wave 2 , the average price of licit packs rose by $4.8 \%$, CI $(0.4 \%$ to $8.1 \%)$, while the average price of illicit packs fell by $20.7 \%$, CI $(-41.2 \%$ to $-8.0 \%)$. After the tax increase (between waves 2 and 3), the price of licit and illicit packs rose by $32.1 \%$, CI ( $10.0 \%$ to $58.8 \%)$ and $32.4 \%$, CI $(0.7 \%$ to $63.4 \%$ ), respectively. The average annual national consumer price indices for imported manufactured cigarettes were $8.6 \%$ from 2017 to 2018 , and $28.9 \%$ from 2018 to $2019 .{ }^{14}$

Table 6 indicates the illicit brands observed in each wave varied. To test whether the average price changes of illicit packs were driven by smokers switching brands or price changes within each brand, we examined the prices of the most popular illicit brand, Manchester. In addition, we analysed price changes for the two most popular licit brands, Winston and Pirveli. On average, illicit Manchester packs were GEL 2.3, CI (2.0 to 2.7) in wave 1 ; GEL 2.1, CI (2.0 to 2.1) in wave 2 and GEL 2.6, CI (2.5 to 2.7) in wave 3. Therefore, the prices of illicit Manchester 
Table 6 Illicit cigarette brands by location of the tax stamp's origin, by wave

\begin{tabular}{|c|c|c|c|c|}
\hline & Wave 1 & Wave 2 & Wave 3 & Total \\
\hline Armada & 1 (unclear/missing) & & $\begin{array}{l}7 \text { (6 unclear/ } \\
\text { missing, } 1 \\
\text { Georgia) }\end{array}$ & 8 \\
\hline Astra & 1 (Georgia) & & $\begin{array}{l}2 \text { (unclear/ } \\
\text { missing) }\end{array}$ & 3 \\
\hline Camel Blue & & & 1 (Georgia) & 1 \\
\hline Chibukh & $\begin{array}{l}1 \\
\text { (Georgia) }\end{array}$ & 1 (Georgia) & & 2 \\
\hline Continent & & $\begin{array}{l}2 \text { (1 Abkhazia } \\
\text { territory, } 1 \text { Russia) }\end{array}$ & $\begin{array}{l}1 \text { (Abkhazia } \\
\text { territory) }\end{array}$ & 3 \\
\hline Get & $\begin{array}{l}2 \\
\text { (Abkhazia territory) }\end{array}$ & & & 2 \\
\hline GM & & $\begin{array}{l}1 \text { (unclearl } \\
\text { missing) }\end{array}$ & & 1 \\
\hline Imperator & & & $\begin{array}{l}1 \text { (unclear/ } \\
\text { missing) }\end{array}$ & 1 \\
\hline Kent & & & 1 (Georgia) & 1 \\
\hline L\&M & 4 (Georgia) & & & 4 \\
\hline Magna & 1 (Georgia) & & 1 (Georgia) & 2 \\
\hline Manchester & $\begin{array}{l}9 \text { (6 Abkhazia } \\
\text { territory, } 1 \text { Russia, } 2 \\
\text { unclear/missing) }\end{array}$ & $\begin{array}{l}34 \text { (31 Abkhazia } \\
\text { territory, } 2 \text { Russia, } \\
1 \text { unclear/missing) }\end{array}$ & $\begin{array}{l}53 \text { (49 Abkhazia } \\
\text { territory, } 4 \\
\text { Russia) }\end{array}$ & 96 \\
\hline Marlboro & 1 (unclear/missing) & & $\begin{array}{l}2 \text { (unclearl } \\
\text { missing) }\end{array}$ & 3 \\
\hline MZE (White) & & 1 (Georgia) & & 1 \\
\hline M1 & & $\begin{array}{l}1 \text { (Abkhazia } \\
\text { territory) }\end{array}$ & $\begin{array}{l}3 \text { (Abkhazia } \\
\text { territory) }\end{array}$ & 4 \\
\hline Phillip Morris & 1 (Georgia) & & $\begin{array}{l}1 \text { (unclear/ } \\
\text { missing) }\end{array}$ & 2 \\
\hline Pirveli & 3 (Georgia) & 1 (Georgia) & & 4 \\
\hline Prima & 1 (Georgia) & & & 1 \\
\hline Samefo & & & $\begin{array}{l}1 \text { (unclear/ } \\
\text { missing) }\end{array}$ & 1 \\
\hline VIP & 1 (Armenia) & & & 1 \\
\hline Wilson Blue & & & $\begin{array}{l}1 \text { (unclear/ } \\
\text { missing) }\end{array}$ & 1 \\
\hline Winston & & & 1 (Georgia) & 1 \\
\hline X1 Silver Slims & 1 (Georgia) & & & 1 \\
\hline \multirow[t]{2}{*}{$\begin{array}{l}\text { Unknown Armenian/ } \\
\text { Abkhazian brand }\end{array}$} & & & $\begin{array}{l}5 \text { (4 Abkhazia } \\
\text { territory, } 1 \\
\text { Armenia) }\end{array}$ & 5 \\
\hline & 27 & 41 & 81 & 149 \\
\hline
\end{tabular}

packs on average fell by $10.1 \%$, CI $(-7.3 \%$ to $-15.3 \%)$ from wave 1 to 2 , and rose by $24.6 \%$, CI (16.5\% to $31.0 \%)$ from wave 2 to 3 . For licit packs, the price of a pack of Winston rose by $10.3 \%$, CI (5.4\% to $13.6 \%)$ from wave 1 to 2 , and by $22.7 \%$, CI (15.1\% to $29.1 \%)$ from wave 2 to 3 . Packs of Pirveli rose by $8.0 \%$, CI $(2.6 \%$ to $12.1 \%)$ from wave 1 to 2 , and by $34.2 \%$, CI (16.0\% to $54.4 \%)$ from wave 2 to 3 . Price outliers at the 1 st and 99th percentile for licit and illicit packs in each wave were excluded for this analysis, to avoid any bias from data capture error.

\section{DISCUSSION}

Between November 2017 and May 2019, the long-term smoking cessation rate was at least $5.6 \%$. This result needs to be interpreted with caution since our sample was not representative of the Georgian population. The rate of cessation was most likely dampened by a shift towards cheaper RYO, particularly after the tax increase. In November 2017, only 1.0\% of smokers consumed only RYO. By May 2019, this share increased to 23.3\% with smokers reporting affordability as the main reason for their switch in wave 3 . The government addressed this substitution by increasing excise tax on RYO products from GEL 35 to GEL 60 per kg in November 2019.

Illicit cigarette consumption was low and did not change significantly in Tbilisi, Kutaisi, Akhaltsikhe and Gori between waves 1 and 3. In Zugdidi, consumption of illegal cigarettes increased substantially from wave 1 to 3 , but this trend already began prior to the tax increase. Zugdidi is located near Abkhazia, the Russian-occupied region, and the Manchester brand was the most common illicit brand dominating all three waves and it was found only in the Zugdidi region. There are still close ties between the regions of Zugdidi and Abkhazia-people are crossing the border back and forth regularly and the border administration is weak. Based on the information received during our FGDs, people buy Manchester cigarettes in Abkhazia, then either bribe the border guards or walk through unchecked. These cigarettes are then sold in markets in Georgia. In all three waves, less than $10 \%$ of illicit packs originated from the neighbouring countries of Russia, Armenia, Turkey and Azerbaijan.

Gori is located near Georgia's second occupied region, South Ossetia, however the situation was different here and we found almost no illicit cigarettes in Gori. Similarly, despite Akhaltsikhe being located near the border with Armenia where cigarettes are cheaper than Georgia, ${ }^{4}$ there were almost no illicit cigarettes in Akhaltsikhe. This points to strong levels of enforcement in these vulnerable areas of Georgia, relative to the Zugdidi region. On average, the prices of illegal cigarettes responded to the tax increase by going up by the same percentage as the legal cigarettes between wave 1 and wave 3 , even though they were still about $50 \%$ cheaper in wave 3 compared with their legal counterparts. The most prevalent illicit brand, Manchester, was cheaper than other illicit brands, and its price changes were more muted compared with other illicit brands. Thus, there is some evidence that smokers of illicit cigarettes may have switched to the Manchester brand for affordability.

Our study has several limitations. First, our sample is not representative of the Georgian population. However, we covered five regions of Georgia to capture any regional differences. Second, not everybody agreed to show a cigarette pack to the surveyor. If the reason was the possession of an illicit pack, then the size of the illicit cigarette market will be biased downwards. This bias may be significant given the low levels of cooperation in Zugdidi, the region with the highest level of illicit consumption. However, respondents were informed that the survey was

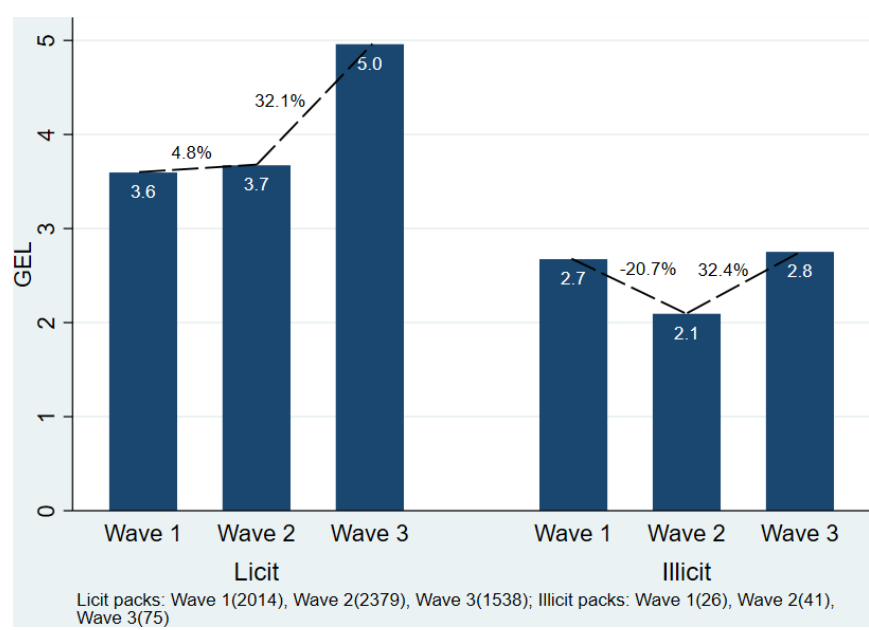

Figure 5 Average price for illicit and licit packs (20 cigarettes) per wave, and price changes. GEL, Georgian lari. 
anonymous to reduce fear of incrimination, and the information from the focus group suggests that the possession of an illicit pack was just one reason for not showing a pack. Further research using littered pack collection in the region of Zugdidi is recommended, because this methodology is free of bias related to the willingness to show a pack. Third, even though we used the presence of a Georgian tax stamp as one of the signs of a legal pack, the authenticity of tax stamps was not tested due to limited budget. Information from the Georgia Customs office received in September 2019 indicates a rare occurrence of counterfeit tax stamps in Georgia. Finally, our study did not assess the legality of RYO, thus we cannot comment on the share of illicit tobacco consumed, only on illicit cigarette consumption. We recommend further research on illicit RYO.

\section{CONCLUSION}

The adoption of fiscal and non-fiscal tobacco control policies in Georgia had no impact on illicit cigarette consumption due to the presence of effective tax administration and enforcement. The illicit cigarette market in Zugdidi that was present already before the adoption of the new policies highlights the importance of war zones and disputed territories in the supply of illicit cigarettes. Georgia should consider tightening controls with Abkhazia and ratifying the Framework Convention on Tobacco Control Protocol to Eliminate Illicit Trade in Tobacco Products as this would strengthen its efforts to control the illicit cigarette market. It will be important to monitor if higher excise taxes on RYO addressed the recent movement from manufactured cigarettes to RYO cigarettes, and further reduced the smoking prevalence. We recommend further exploration of the impact of the tax increase and other policy changes on illicit tobacco market in Georgia using multiple methods and nationally representative data.

\section{What this paper adds}

What is already known on this subject

- In Georgia and elsewhere, the tobacco industry argues that increasing cigarette taxes leads to a rise in illicit cigarette consumption. A study published in this journal in 2020 showed that the illicit cigarette penetration in Georgia was low despite recent tobacco tax increases. However, it could not establish a relationship between a change in tax and a change in the cigarette illicit trade.

\section{What this paper adds}

- This study consistently measures the size of illicit cigarette market in five regions of Georgia from 2017 to 2019, a period when both new non-fiscal policies and higher taxes were implemented. The results show no country-wide increase in illicit tobacco consumption but point to a regional problem of an illicit cigarette market that persists over time and is related to the disputed border area occupied by Russia. We conclude that illicit cigarette trade in Georgia is not related to tax changes or changes to other tobacco control policies, but to border security.

\section{Twitter George Bakhturidze @George Bakhturidze}

Acknowledgements We would like to thank Mike Bowling for assistance in designing the sampling frame, Kakha Gvinianidze for his support, the surveyors for their hard work, and all survey respondents.
Contributors HR conceptualised the research and designed the questionnaires with the input from the rest of the team. GB is the principal investigator and managed the project in Georgia. IK managed the data collection. ML and IK analysed the data. The results were synthesised and written by ML and HR.

Funding This research was made possible by funding from the Cancer Research UK (IRMA number 30845).

Map disclaimer The depiction of boundaries on the map(s) in this article does not imply the expression of any opinion whatsoever on the part of BMJ (or any member of its group) concerning the legal status of any country, territory, jurisdiction or area or of its authorities. The map(s) are provided without any warranty of any kind, either express or implied.

\section{Competing interests None declared.}

\section{Patient consent for publication Not required.}

Ethics approval The survey was executed following the ethics rules of the Republic of Georgia and received ethics approval from the University of Cape Town's Faculty of Commerce Ethics Board (REF: REC 2019/000/051).

Provenance and peer review Not commissioned; externally peer reviewed.

Data availability statement We will be making the data collected during our three waves of data collection in Georgia publicly available through the University of Cape Town's DataFirst as our data publishing repository and the data will be deidentified with no personally identifiable information of the participants made publicly available.

Open access This is an open access article distributed in accordance with the Creative Commons Attribution 4.0 Unported (CC BY 4.0) license, which permits others to copy, redistribute, remix, transform and build upon this work for any purpose, provided the original work is properly cited, a link to the licence is given, and indication of whether changes were made. See: https://creativecommons.org/ licenses/by/4.0/.

\section{ORCID iD}

Megan Little http://orcid.org/0000-0002-2110-4509

\section{REFERENCES}

1 Williams J, Rakovac I, Loyola E, et al. A comparison of self-reported to cotininedetected smoking status among adults in Georgia. Eur $J$ Public Health 2020;30:1007-12.

2 Bakhturidze G. Tobacco control policy development and progress in Georgia. Jhi 2018;4:90-4.

3 Agenda.GE. Cigarette prices increase in Georgia by an average of 50 tetri. Tbilisi, Georgia, 2019.

4 World Bank. Confronting illicit tobacco trade: a global review of country experiences. Washington DC: WBG Global Tobacco Control Program, 2019.

5 Ross $\mathrm{H}$, Vellios N, Batmunkh T, et al. Impact of Tax increases on illicit cigarette trade in Mongolia. Tob Control 2020;29:s249-53.

6 Paraje G. Illicit cigarette trade in five South American countries: a gap analysis for Argentina, Brazil, Chile, Colombia, and Peru. Nicotine Tob Res 2019;21:1079-86.

7 Shalutashvili A, Ross H, Watt J. Tobacco economic study in Georgia since the fall of the Soviet Union. Tbilisi: FCTC Implementation and Monitoring Center in Georgia, 2007.

8 Little M, Ross H, Bakhturidze G, et al. Illicit tobacco trade in Georgia: prevalence and perceptions. Tob Control 2020;29:5227-s233.

9 Ross H. Understanding and measuring cigarette Tax avoidance and evasion, a methodological guide. Washington DC, 2015. Available: http://www.tobaccoecon.uct. ac.za/sites/default/files/imagetool/images/405/Publications/reports/Understandingand-measuring-tax-avoidance-and-evasion-A-methodological-guide1.pdf

10 National Statistics Office of Georgia. Demographic situation in Georgia. Tbilisi: Population Census and Demographic Statistics Department, National Statistics Office of Georgia, 2019.

11 Milanese R. Facilitating document and physical inspection of excisable goods. In: WCO IT/TI Conference \& Exhibition 2019 [Internet]. Azerbaijan. SICPA, 2019. Available: https://na.eventscloud.com/file_uploads/fb677e6da76a05fe53c62f5c87d3de95_1_ RuggeroMilaneseSICPA.pdf [Accessed 17 Apr 2021].

12 National Statistics Office of Georgia [Internet]. Gross domestic product (GDP). Tbilisi: Geostat. Available: https://www.geostat.ge/en/modules/categories/23/grossdomestic-product-gdp [Accessed 20 Mar 2021].

13 National Statistics Office of Georgia [Internet]. Consumer price index (inflation). Tbilisi: Geostat. Available: https://www.geostat.ge/en/modules/categories/26/cpi-inflation [Accessed 20 Mar 2021].

14 National Statistics Office of Georgia [Internet]. Consumer price index (inflation): consumer price detail annual indices. Tbilisi: Geostat. Available: https://www.geostat. ge/en/modules/categories/26/cpi-inflation [Accessed 20 Mar 2021]. 